Western University Scholarship@Western

1991

\title{
The Cycle Before New-Classical Economics
}

David Laidler

Follow this and additional works at: https://ir.lib.uwo.ca/economicsresrpt

Part of the Economics Commons

Citation of this paper:

Laidler, David. "The Cycle Before New-Classical Economics." Department of Economics Research Reports, 9115. London, ON: Department of Economics, University of Western Ontario (1991). 
ISSN : $0318-725 x$

ISBN : $0-7714-1.347-5$

\author{
RESEARCH REPORT 9115 \\ THE CYCLE BEFORE \\ NEW-CLASSICAL ECONOMICS \\ by \\ David Laldler
}

November 1991

\author{
Department of Economics \\ Social Sclence Centre \\ UnIversity of Western Ontario \\ London. Ontario. Canada
}

N6A $5 \mathrm{C2}$

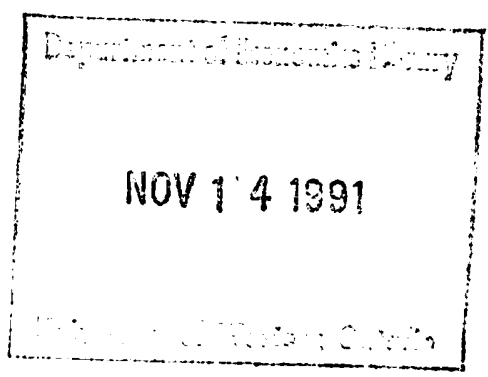




\title{
THE CYCLE BEFORE NEW-CLASSICAL ECONOMICS*
}

by

\author{
David Laidler
}

\section{University of Western Ontario and}

C.D. Howe Institute

* Paper presented at a conference on the business cycle held at the Federal Reserve Bank of St. Louis in October 1991. I am grateful to Andreas Hornstein, Peter Howitt, Michael Parkin, and Steve Williamson for comments on an earlier draft, but do not wish to implicate them in my views: 


\section{INTRODUCTION}

If an idea is to be influential in economics it is not enough that it be a good idea. Economists must also be convinced of its quality, and this is not achieved simply by demonstrating theoretical rigour and empirical relevance. It also involves the use of persuasive language. The formal study of "The Rhetoric of Economics", of which be it said, the use of persuasive language is but one component, is of more recent origin than the phenomenon itself. It was, after all, Keynes, not Donald McCloskey (1983) who said: "Words ought to be a little wild for they are the assault of thought upon the unthinking." Even so, recent developments in business cycle theory provide a striking example of the power which the right words have to draw attention to an idea. ${ }^{1}$ Who, when all is said and done, could resist the appeal of a "real" theory of the business cycle? How could it fail to be better than, shall we say, a "mythical" theory? And if it wins hands down in this comparison, might it not also turn out to be more satisfactory than a "monetary" theory too? That is surely Kydland and Prescott's (1990) underlying message, and to judge by the literature which has built upon their original (1982) work, they have been remarkably successful in getting it across.

But the language used to promote modern business cycle theory is, in the context of this paper, misleading. The major innovation of Kydland and Prescott has been to build a plausible model of the cycle in which the dominant impulse (to borrow a phrase from Brunner and Meltzer (e.g. 1978)) arises from shocks to the aggregate production function, rather than to aggregate demand. Though it is true that monetary shocks provide a genuine alternative to those hypothesised by Kydland and Prescott, it is also the case that, except in the literature based on the twin assumptions of (Walrasian) clearing markets and rational expectations, monetary-impulse models have always been something of a minority taste. In the literature of 
the 1950s and 1960s, and long before that too, "real" theories of the cycle predominated, though those were very different from anything that currently carries that label.

Modem business cycle theory is based on Walrasian general equilibrium analysis. In such a system markets always clear and the distinction between "demand" and "supply" shocks is not all that helpful: Say's law holds, supply creates its own demand, and in general any shock will affect both simultaneously. The demand-supply shock distinction does make sense in a system in which the fact of monetary exchange permits aggregate demand and supply to move independently of each other and in which, therefore, a situation of general excess demand or supply can emerge. The appropriate contrast, then, between Kydland and Prescott's work and that of the 1950s and 1960s, is not between "real" and "monetary" models, but between those which locate the shocks initiating the cycle in the economy's production sector and in which both supply and demand behaviour interdependently respond, and those which locate them on the demand side, and treat production as passively adjusting to demand fluctuations whose origins can be either real or monetary.

It is also worth noting that some advocates of "real business cycle theory" - eg. Plosser (1990) have lately taken to classifying anything but a change in the monetary base, including a change in the required reserve ratio, as a "real shock". They cannot be prevented from using the word "real" this way, but they should make it clear to their readers that it is then appropriate to use the adjective "nominal" rather than "monetary" to characterise an alternative approach. This matter is important, because every monetary theory of the cycle of which I am aware has paid careful attention to, and indeed usually accorded prime importance to, endogenous fluctuations in money multipliers (and in the case of 1937-38 to changes in reserve requirements too) when confronting empirical evidence. No-one, to the best of my knowledge, ever advanced a purely nominal theory of the cycle as a serious explanation of any actual historical experience. 
None of this would matter very much if inability to cope with empirical evidence was a characteristic of all demand side models of the cycle. But in fact the models which found themselves in trouble from the mid-1960s onwards were real (albeit demand side) models, and these were already in difficulty as a result of a re-examination of previous empirical evidence. The historical studies of Friedman and Schwartz had, by the mid 1960s, established what we would nowadays call the monetarist explanation of the cycle as something to be taken very seriously. Subsequent experience with inflation and unemployment, which was so damaging to the orthodox Keynesian demand-side macroeconomics of the time, did nothing to undermine Monetarism. Nor is the stylised fact that the price level has moved in a generally counter-cyclical fashion in the post war years, of which Kydland and Prescott (1990) make so much, damaging to monetarist models of this vintage.

It is indeed true that assertions to the effect that the price level is a pro-cyclical variable are to be found in the literature. ${ }^{3}$ It is also true, as Kydland and Prescott (p.7) remark, that "... if these perceptions are not in fact the regularities, then certain lines of research are misguided", and that, as they further suggest, the equilibrium monetary models of the 1970s are vulnerable to such criticism. Monetarist models of the 1960 s - early 1970s, however, were not constructed to predict any such fact. Nor, incidentally, did they rely on the postulate that "... the money stock, whether measured by the monetary base or by $M_{1}$ leads the cycle" (p. 5). Hence, Kydland and Prescott's exposure of this postulate as yet another "misperception" also leaves monetarist models unscathed.

In the following pages, I shall first give an account of how business cycle theory fitted into the macroeconomic consensus of the 1950s and early 1960s, and then discuss Monetarism's role in disturbing this aspect (along with many others) of the consensus in question, paying particular attention to the predictions of monetarist models about the cyclical behavior of money and prices. I shall go on to argue that the main strength of later New-classical economics, in the 
Lucas-Sargent-Wallace mode, was not so much its explanatory power, as its conformity to particular a priori methodological criteria, and that modern real business cycle theory also conforms to those criteria, whose appeal is understandable in the light of those earlier debates. I shall argue that the criteria in question are insufficient to establish the superiority of modem real business cycle theory, and that it therefore remains open to empirical challenge from an alternative approach to which the monetarist economics of the 1960 s made a vital contribution.

\section{II}

\section{THE RISE AND FALL OF MULTIPLIER-ACCELERATOR THEORY}

Before the publication of the General Theory, the business cycle occupied a central position in what we would nowadays call macroeconomics. Though it shared the stage with inflation, the fact that many monetary models of the cycle treated inflation as an integral characteristic of the cycle's upswing meant that divisions here were not sharply marked. The essentially comparative static analysis of the General Theory, and of the IS-LM model which came to be regarded as embodying its central theoretical contribution, shifted the focus of macroeconomics away from cycle theory, but there was more to the "Keynesian Revolution" than that. 4

Whatever Keynes may have meant, Keynesian economics downgraded the importance of monetary factors as an explanation of macroeconomic phenomena. The empirical postulates that the demand for money was highly interest elastic, and probably unstable too, and the belief that expenditure, again as an empirical matter, was insensitive to interest rates, implied that the real side of the economy, as described by the IS curve, must be the source of economic disturbances. An alleged empirically stable marginal propensity to save underpinned 
a stable multiplier. Hence fluctuations in investment came to be regarded as the main factor driving movements in real income and employment, with variations in interest rates playing at most a marginal and complicating role in the process.

Although, with the onset of the Keynesian Revolution, models of the cycle which located the impulses driving it in the monetary sector therefore vanished from the mainstream of the literature, cycle theory continued to flourish as an important component of the sub-discipline, requiring the inclusion of a chapter or two in any intermediate textbook, and the production of supplementary textbooks and collections of readings for more advanced students. The comparative statics of real income determination, embodied in IS-LM analysis, had to be grasped as an end in themselves, but, for serious students, mastering them was also an essential preliminary to coming to grips with "multiplier-accelerator" models which treated the cycle as the outcome of systematic rightward and leftward shifts of the IS curve along an essentially horizontal LM curve. 5

The pre-General Theory literature had contained a number of "real" theories of the cycle. Jevons' speculations about the importance of fluctuations in agricultural output stemming from sunspot activity continued to attract attention well into the 1920 s, operating, in the hands of Pigou, in combination with the notion that business investment was subject to influence from waves of optimism and pessimism. Schumpeter argued that investment fluctuated because of irregularities in the pace of innovation, and that the cycle was an integral component of the process of capitalist growth. Though all of these approaches found a role for monetary factors, it was a strictly supporting one; but viewed from the perspective of IS-LM analysis they were analytically uninteresting. In that framework they provided little more than reasons, endogenous to the economy perhaps, but exogenous to the model, why the IS curve might shift back and forth over time. 
The accelerator hypothesis was also well developed in that earlier literature, usually being deployed to explain the relatively large aplitude of cylical fluctuations in investment, but it had not found a home in any complete model of endogenous (cyclical) fluctuations. Keynesian economics provided the requisite accommodation, and the accelerator tumed out to be the perfect partner for the multiplier, in a union forged by exponents of the analytic techniques (then newly available to economists) of difference and differential equations. The idea of the accelerator as it appeared in the resulting models was simple enough. Suppose that the economy is characterised by a fixed coefficients production function, that capital is fully utilised, but that labour is freely available. Then any increase in the demand for real output will require firms to acquire new capital equipment to produce it. The rate of investment will thus be linked to the rate of change of output by a parameter given by the capital output ratio. Investment, however, will have a multiplier effect on output, which in turn will feed back through the accelerator to investment. In discrete time, this interactive process may be made to yield a second order difference equation, whose dynamic properties might be monotonic, cyclical, damped, explosive, etc., depending upon the precise values of the parameters of the multiplier and accelerator relationships. ${ }^{6}$

But the incorporation of the accelerator into Keynesian economics was not just a matter of the application of technique for technique's sake. The General Theory had made much of the influence of investment on the level of aggregate demand for goods and services, but had carefully avoided dealing with its other role in changing the economy's productive capacity. As Harrod (1948) and Domar (1947) each showed, a time path for aggregate demand generated by a particular time path of investment could only be an equilibrium path if investment was simultaneously providing just the right amount of capacity to meet the demand in question. The first of these two relationships involved the multiplier, and the second the economy's capital output ratio and hence the accelerator relationship. Multiplier-accelerator interaction thus seemed to provide the key to extending Keynesian economics into a system 
which could deal with both growth and cycles. The economy's growth path would, within a limit given by population growth, be the steady state of the same process driving the cycle, and of course the policy implications of Keynesian analysis pointed to the possibility both of stabilising the cycle and manipulating the economy's steady state, or warranted, growth path so that it coincided with that of the labour force, and hence the economy's natural growth path.

Now multiplier accelerator interaction is capable of generating virtually any type of dynamic behaviour, depending on the size of the relevant coefficients, but it seemed to some, notably Hicks $(1949,1951)$, that the accelerator was, as an empirical matter, powerful enough to produce a monotonically explosive time path for income's deviation from its steady state path. This presumption formed the basis of his famous "non-linear" cycle model, whose qualitative characteristics are easily described. Begin in the middle of an upswing, with output moving along an explosive expansionary path, and note that output must eventually reach a level at which its subsequent rate of growth will be constrained by that of the labour force. When output growth is thus constrained, investment will fall and a downward multiplier effect will set a downswing in motion. Since, with durable capital, the flow of net investment cannot fall below the rate of depreciation of the actual capital stock, the multiplier alone will carry the economy to a floor whose value is determined by some exogenously given level of autonomous expenditure. Once at the floor, existing surplus capital will wear out, and when it eventually does, an injection of replacement investment demand will set an explosive upswing going again.

A number of points are worth making about this model. First, it treats the cycle as an entirely "real" phenomenon, with the demand side of the economy dominating the upswing and downswing phases of the cycle, but supply side phenomena providing the constraints which generate its turning points. Second, the cycle it produces is completely self-generating and poses no questions about what kind of impulse might set it in motion. Third, difficult though 
it is to defend it now, this model did, until the mid-1960s dominate the chapters devoted to the cycle in the intermediate textbooks. Its demise, however, was not the result of the rise of Monetarism. It is more accurate to argue that the popularity of monetarist analysis of the cycle resulted from its ability to fill a gap in macroeconomics created by the fact that the Hicks cycle model, and the many variations on it that the literature contained, failed to survive developments which took place within mainstream macroeconomics during the 1950s. It will suffice to enumerate these.

First, the "new" theories of the consumption function of Friedman (1957) and Modigliani and Brumberg (1954) suggested that though the marginal propensity to consume out of permanent, or life cycle, income might be stable, this did not imply that the marginal propensity to save out of current income, and therefore the multiplier, was also stable. Second, the Neo-classical model of Meade (1961), Solow (1956), and Swan (1956) soon took over from the Harrod-Domar model as the centrepiece of growth theory and used a variable proportions production function. Hence the capital output ratio became an endogenous variable, whose long run equilibrium value was determined as part of the outcome of a process whereby the economy converged smoothly to full employment growth path determined by the rate of growth of the labour force. In the light of this analysis it became indefensible to treat it as the key structural parameter linking the growth process to an endogenous cycle. Third, work on the microeconomics of the accelerator, as surveyed by Knox (1952), reduced it to little more than a proposition that investment would be some distributional lag function of the difference between the desired and actual capital stock. Here too, variable proportions were the order of the day, and in the slightly later work of Jorgenson (e.g. 1963), a variable linking the real and monetary sectors, namely the rate of interest, re-emerged as a component of the cost of capital, and hence as a determinant of the desired capital stock and an argument in the investment function. 
What came to be called the "flexible accelerator", derived from the capital stock adjustment principle, involved the inclusion of forward looking variables in investment equations, to capture the expected profitability of new capital equipment; and, analytically closely related, the new theories of the consumption function modelled consumer expenditure decisions as being inherently forward looking. But expectations were usually modelled as distributed lag functions of the variables they concerned, while adjustment processes gave rise to similar functional forms. As early as 1962, then, a new textbook, in my view the best (but probably not best selling) of its time (Martin J. Bailey (1962)) had replaced the obligatory chapter on multiplier accelerator interaction with one entitled "Expectations and Adjustment to Change: A Key Link in Cumulative Movements of the Economy." But expenditure functions based on these ideas were much less prone to generate explosive behaviour. Rather they tended to produce persistent but damped fluctuations which required exogenous shocks to get and keep them going. And models containing them were no longer simple multiplier-accelerator systems.

The aim of modern real business cycle theory is to produce an integrated account of growth and cycles, firmly based on sound micro-economic foundations. We have now seen that the integration of growth and cycle theory was also the aim of multiplier-accelerator theorists. It is ironic, therefore, that their work foundered on the results generated by the first round of efforts to produce more satisfactory micro-foundations for macroeconomics. Though multiplier-accelerator models lingered on in many textbooks for another decade or more, they had ceased to be the centre of active research effort by the early 1960s. The next round of work on the cycle moved in two directions, at first largely separate and distinct from one another, each dealing with a separate component of Ragnar Frisch's (1933) agenda for this area. First, the demise of the self perpetuating cycle models meant that the temporarily suspended search for exogenous impulses had to be taken up again. Second, the study of propagation mechanisms moved away from the analysis of low order difference and 
differential equation systems which had characterised multiplier accelerator theory into the domain of the large econometric models whose complex distributed lag structures required numerical simulation exercises to reveal their dynamic properties. ${ }^{7}$ These two endeavours were not logically incompatible with one another, but, as a matter of fact, Monetarism came to dominate the first, while an eclectic type of Keynesian economics was perpetuated in the second.

III

\section{MONETARISM AND THE CYCLE}

The literature of what later came to be called Monetarism is as complex as its intellectual roots are varied. It dealt with inflation and monetary policy, as ell as the business cycle. That part of it dealing with the positive theory of the cycle, drew heavily of the National Bureau tradition of Burns and Mitchell (e.g. 1946), whose work Koopmans (1947) disparagingly characterised as "Measurement without Theory." In this case, though, a more accurate description might be "measurement before theory." Friedman's earliest published studies concentrated on describing certain persistent quantitative relationships among the behaviour of the money stock, money income, real income, prices and so on; only later, partly in response to critics, was the theoretical framework in terms of which those observations could be explained and interpreted revealed, a framework which, as is by now well understood, was differentiated from that of the then prevailing Keynesian orthodoxy more by its quantitative than its qualitative characteristics. ${ }^{8}$

Friedman's (1958) study for the Joint Economic Committee of Congress was mainly concerned with describing both the secular and cyclical relationships between money and prices revealed in United States data, and it was there that he pointed to the fact that the rate of change (not the level) of the stock of money displayed". . .well marked cycles that match closely those in 
economic activity in general and precede the latter by a long interval" (p.181) Though Friedman was careful to deny unidirectional causation here, because "The character of our monetary and banking system means that an expansion of income contributes to an expansion of the money stock. . .similarly a contraction of income contributes to a reduction or slower rate of rise in the money stock. . " (p.179), he nevertheless insisted that regardless of their source, changes in the rate of money growth would have subsequent effects on economic activity in general, and on the time path of prices in particular. Hence, monetary changes affected the economy with a long and variable time lag. Subsequent monetarist work on money and the cycle elaborated these basic themes.

Friedman and Schwartz's (1963a) Monetary History of the United States, among many other things, documented the above relationships on a cycle by cycle basis, and established that the predominance of money growth as a causative factor was more easily discerned in the violent fluctuations which marked the inter-war years than at other times. Drawing on the then unpublished work of Phillip Cagan (1965), it also established that changes in the stock of money were predominantly the result of variations usually endogenous, but sometimes, notably in 1937, the result of regulatory changes in the banking system's demand for reserves relative to deposits, and in the public's currency to deposit ratio, hence confirming the cumulative and interactive nature of money's relationship to the cycle. And Friedman (1961) and Friedman and Schwartz (1963b) explained the transmission mechanism through which variations in money growth affected the economy, something which had been very much missing from Friedman's first account of this matter, and an omission for which he was frequently criticised long after he had repaired it. Two matters are important here, the first being why the rate of money growth rather than the level of the money stock is the important impulse variable, and the second being how such an impulse could lead to the fluctuations which we call the cycle. 
Friedman stressed in more than one place that one element in the case for paying attention to money's rate of change was statistical. The stock of nominal money is a heavily trended variable, and its percentage rate of change (log. first difference) is not. But the process of first differencing moves the monetary impulse forward in time and, as John Culberston (1961) pointed out, opens up the possibility that the "long and variable" time lag is purely a statistical artifact. The level of the nominal money supply was (as Kydland and Prescott have recently reminded us) not so much a leading as a co-incident variable. There was a good theoretical reason for treating changes in nominal money growth as the critical monetary impulse, however, and Friedman's (1961) account of it, offered in response to Culbertson, is worth quoting at some length.

"Consider a hypothetical long-run moving equilibrium in which both output and the stock of money are rising at constant percentage rates, the rise being fully anticipated so that actual, expected, and desired stocks of money are equal. The result would be a roughly constant percentage rate of change of prices. . The percentage rate of change of prices itself is the opportunity cost of holding money rather than goods, so a constant rate of change in the stock of money corresponds to a constant opportunity cost of holding money. . .An unanticipated change in the rate of change of the stock of money would then produce a deviation of the actual from the desired stock of money for two reasons: initially, it would make the actual stock deviate from the expected stock and therefore from the desired stock; subsequently, by altering the cost of holding money, it would change the desired stock itself. These discrepancies will set up adjustments that may very well be cyclical. . .It is therefore theoretically appealing to regard the "normal" or secular monetary base (sic) around which cyclical fluctuations occur as described by a constant percentage rate of change in the stock of money and to regard changes in the percentage rate of change as the feature of monetary behaviour that contributes to the generation of cycles." (p. 247) 
For Friedman, that is to say, a monetary surprise constituted the cyclical impulse, and a change in the rate of marginal money growth marked its occurrence. But, although his monetarism had this much in common with the later New-classical analysis of Lucas et al., its view of the subsequent propagation process, what used to be called the "transmission mechanism", was very different. Indeed, it was very much in line with what we nowadays usually think of as Keynesian economics, as the following summary of Friedman and Schwartz's (1963b pp. 229-234) account of the matter makes clear. ${ }^{9}$

Beginning in precisely the moving long-run equilibrium just described, they postulate a once and for all change in the rate of monetary growth, brought about by". . .an increased rate of open-market purchases by a central bank." They then point out that "Although the initial sellers of the securities. . were willing sellers, this does not mean that they want to hold the proceeds in money indefinitely." They sold because they were offered a good price, not because their cash balances were deficient, and hence will ". . .seek to readjust their portfolios." To the extent that these original purchasers were commercial banks, moreover, this effort will involve a further round of credit and hence money creation. Be that as it may, "It seems plausible that. . holders of redundant balances will turn first to securities similar to those which they have sold, say, fixed interest, low-risk obligations. .."; but this will bring about a rise in the price of such securities which will spread to other assets:

- ". . higher-risk fixed-coupon obligations, equities, real property and so forth. . .These effects raise demand curves for current productive services, both for producing new capital goods and for purchasing current services. The monetary stimulus is, in this way, spread from the financial markets to the markets for goods and services."

Output and prices will begin to rise, and money income will tend to overshoot its new equilibrium time path, both because, as higher inflation becomes anticipated, the economy's 
demand for real balances falls, and also because second and subsequent round influences on deposit-currency ratios will affect the behaviour of money growth relative to its ultimate equilibrium.

In New-classical analysis, a monetary surprise affects output because, although the price level moves instantaneously to restore equilibrium between the supply and demand for nominal money, that movement is misperceived by agents who react by increasing their supply of goods and services, and its effects are spread out over time because of costs of adjusting quantities supplied. In stark contrast, for Friedman and Schwartz, persistent portfolio disequilibrium and its effects on flows of expenditure is of the essence:

"The central element in the transmission mechanism. . is the concept of cyclical fluctuations as the outcome of balance sheet adjustments, as the effects of flows on adjustments between desired and actual stocks. It is this interconnectedness of stocks and flows that stretches the effect of shocks out in time, produces a diffusion over different economic categories, and gives rise to cyclical reaction mechanisms. The stocks serve as buffers or shock absorbers of initial changes in rates of flow, by expanding or contracting from their "normal" or "natural" or "desired" state, and then slowly alter other flows as holders try to regain that state." (p. 234)

Since among the stocks to which Friedman and Schwartz explicitly drew attention were those of consumer durables and fixed capital, there was no reason at all why their view of the monetary impulse could not have been combined with a real propagation mechanism of the type referred to above incorporating a flexible accelerator mechanism, in order to produce an eclectic account of cyclical fluctuations. Matters did not at first develop in this way, however. While the quantitative analysis of these real propagation mechanisms advanced in the context 
of work on large scale econometric models, a separate literature debated the monetarist view of the primacy of monetary impulses.

The debate about the monetary origins of the cycle was untidy, and drawn out. It touched on general issues concerning the difficulty of deriving conclusions about the direction of causation between variables from data on timing, and about whether Friedman's (1959) view of the empirical nature of the demand for money function as being essentially devoid of significant interest rate effects, had led him and his associates to pay insufficient attention to the possibility that non-monetary impulses might sometimes be important. ${ }^{10}$ But when these issues had been settled in favour of the critics - data on timing might indeed be misleading, and velocity was after all interest sensitive so money income could fluctuate even if money did not - that still left the core of the monetarist case undamaged. It had been advanced, not as a set of theorems that were true of logical necessity under any conceivable circumstances, but as a collection of falsifiable hypotheses about how real world data had been generated. Much, though not all, of the debate about these hypotheses concentrated upon a particular episode, namely the Great Depression, and for a number of very good reasons.

First, the episode in question had generated sufficiently large swings in the data that it seemed likely that they might permit discriminating tests to be carried out. Second, and closely related, Friedman and Schwartz had used their interpretation of the Depression (and of one or two other relatively major fluctuations) to establish an a priori presumption of the importance of money for milder cycles, where the data made it much harder to allocate cause and effect. Finally, and decisively, though the actual history is a good deal more complicated, in the mythology of the mainstream economics of the 1950s and 60s, the Depression was the episode which had given birth to the Keynesian revolution in economic thought. To argue that the causes of the Great Depression were monetary, then, was to mount a challenge to that mythology which could not be ignored by Keynesians, in whose thetoric it supplied the 
example par excellence of the irrelevance of money in general, and the impotence of monetary policy in particular.

But it turned out to be hard indeed to undermine Friedman and Schwartz's account of the Depression. They attributed some causative significance for the initial downturn, which more or less co-incided with the 1929 stock market crash, to a preceding slowdown in the growth of the monetary base, and hence of the money supply. However, their key claim was that a sharp recession turned into a major catastrophe because the Federal Reserve failed to prevent a series of bank failures. The first round of these occurred in 1930, and precipitated large increases in reserve and currency deposit ratios, which led to a collapse of money growth. In Friedman and Schwartz's view, this collapse was the proximate cause of falling prices and output. From 1931 till 1933, this "great contraction" fed upon the further bank failures which a continued absence of lender of last resort action on the part of the Federal Reserve permitted to occur. After 1933, the monetary base continued to grow (as it had since late 1930) but was mainly absorbed into bank reserves; and according to Friedman and Schwartz this showed not that the Fed was "pushing on a string", but rather that surviving banks had a well developed, and easily justified, appetite for free reserves. This hypothesis found support in the fact that, when reserve requirements were increased in 1937 to absorb what the Fed believed to be excessive bank liquidity, the banks responded by restoring their free reserve levels, in the process causing a money growth slowdown which brought on the 1938 contraction. ${ }^{11}$

In short, endogenous cumulative interaction between the quantity of money and the cycle, which the authorities could have, but did not, offset, rather than some mechanical one way link between exogenous money and endogenous income, was at the heart of Friedman and Schwartz's story. And indeed, in their original exposition, they were careful not to identify the mild monetary slowdown that began in 1928 as the only plausible explanation for the initial onset of the contraction. Thus, though other scholars could, and did, point to the 
Smoot-Hawley tariff, bank failures in Europe, problems in the U.S. housing market, and so forth, as other important contributing factors, such arguments left the core of the monetarist case untouched. Only Peter Temin (1976) attempted to rebut that core. He pointed out that, after the bank failures of 1930, real balances continued to grow, and nominal interest rates to fall, and argued that these facts were prima facie evidence that monetary contraction was a purely passive response to a downtum whose fundamental cause was real, namely a downwand shift of the consumption function.

There is not space here to survey the debate which Temin provoked. Suffice it to note his arguments failed to convince the majority of his colleagues, who wondered, for example, whether the supply of real balances might not have expanded less than the demand for them between 1929 and 1931, or whether nominal rates of interest were a reliable sole measure of the opportunity cost of holding money during a period of great financial uncertainty and rapidly falling prices. Mayer (1978) showed that Temin's postulated downward shift of the consumption function was very sensitive to his choice of data. And this is not to mention the difficulty involved in attempting to re-instate a Keynesian interpretation of the Depression on the basis of instability of the consumption function, of all relationships! All in all, the criticism their work provoked failed to undermine Friedman and Schwartz's re-instatement of the importance (though not the sole importance) of monetary influences on the Great Depression. Certainly, as Karl Brunner (1981 p. 316) remarked, "The story of a powerless Central Bank acting valiantly but in vain in order to contain the economic storm. .." was effectively disposed of by the controversies of the 1960 s and 70 s. The status of the monetary explanation of the cycle was thus considerably enhanced, even though, as Brunner also noted, these controversies stopped well short of establishing monetary shocks as the sole impulse driving the cycle during the 1930s, let alone at other times. 
Nor, by and large, did the econometric studies of the time convincingly establish money's dominance during the depression. Friedman and Meiselman's celebrated (1963) Commission on Money and Credit paper, whose central thrust was to compare the explanatory power over the time path of nominal consumer spending of variations in autonomous expenditure on the one hand, and the money supply on the other, and which found that the money supply seemed to perform much better on average, nevertheless attributed an important influence to variations in autonomous expenditure during sub-periods dominated by the $1930 \mathrm{~s} .{ }^{12}$ And, as Ando and Modigliani (1965) and DePrano and Mayer (1965) soon showed, the apparent dominance of money in other periods was very sensitive to the way in which autonomous expenditure was defined. It is true that Andersen and Jordan's (1968) methodologically closely related study of the relative effects of money and fiscal variables found little role for the latter, but fiscal policy is not quite the same thing as autonomous expenditure in general, and Anderson and Jordan did not study the 1930 s, but only the post war period.

In short, though the debates of the 1960 s and early 1970 s did re-establish monetary factors as being far more important than the almost exclusively real business cycle models of the preceding two decades had allowed, a dispassionate reading of their outcome surely supports an eclectic, rather than monocausal monetary interpretation of the cycle. ${ }^{13}$ Interest in the work which seemed to be leading to this conclusion faded, however, before such a result became firmly established, as macroeconomics took up and debated a specific relationship which was to be of central importance to the evolution of cycle theory during the 1970 s and 80s. I refer, of course, to the Phillips curve. 


\section{IV \\ THE PHILLIPS CURVE AND STICKY PRICES}

Friedman and Schwartz (1963b) were more precise about the way in which monetary changes would affect the nominal demand for goods and services than about how real income and prices would separately react to demand side shocks. In this their analysis was completely representative of its time. The Keynesian economics of the post-war period was above all an economics of real income determination, and as we have seen the multiplier-accelerator theory of the cycle that went along with it was a completely real model. Though, in their work of the 1950s, Friedman and his associates were far from the Keynesian mainstream in the attention they paid to price level behaviour, this was in contexts where output changes could be ignored. The macroeconomics of the 1950s, that is to say, could deal with real output fluctuations, or inflation, but not the two simultaneously and separately.

A.W. Phillips, had encountered just this problem in constructing an analytic cycle model for the study of stabilisation policy as an application of control theory. He had "solved" it in (1954) with an equation in which the rate of price inflation varied with the excess demand for output. In 1958, in a paper which was essentially a by-product of the above mentioned research agenda, he showed that there appeared to have existed, in almost a century of United Kingdom data, a rather stable relationship between the rate of money wage inflation on the one hand and the level of unemployment and its rate of change on the other. ${ }^{14}$ This "Phillips Curve" provided the prototype for equations which could be inserted in econometric models to allocate fluctuations in nominal income between real output and the price level; and in an apparently natural policy application, it also permitted the effects of stabilisation policy on the inflation rate, as well as the level of income and employment, to be discussed. It was quickly absorbed into the mainstream of Keynesians macroeconomics, therefore, but remained an 
object of considerable suspicion among exponents of a monetary approach to cycle theory who were enamoured of neither large econometric models nor stabilisation policy.

Analysis of the Phillips curve's theoretical foundations soon uncovered difficulties. Richard Lipsey (1961), elaborating on Phillips' own very sketchy suggestions, argued that the unemployment rate should be interpreted as a proxy variable for the excess demand for labour, and wage inflation's responsiveness to it as nothing more than a manifestation of the general tendency of any price to respond to excess demand. As Edmund Phelps (1967) and Friedman (1968) soon pointed out, however, the relevant price here, according to standard economic theory, was the real and not the money wage; so that the apparently permanent inflation-unemployment trade off promised by the Phillips curve ought to be at best a temporary phenomenon, stemming from a tendency for agents' expectations of inflation to lag behind experience. Though this point was quickly and widely accepted as theoretically correct, the apparent weight of empirical evidence to the contrary led many commentators Solow (1968) and Tobin (1972) provide examples - to argue, as a practical matter, that agents either did not fully adjust their expectations to experience, or that the frictions of a less than perfect labour market prevented them from acting upon those expectations. Hence the first impact of the Phelps-Friedman critique of the Phillips curve was to persuade its proponents to distinguish between long and short run inflation-unemployment trade-offs, and to accept that the former might be less favourable than the latter. It did not, however, convince them that it was non-existent.

The catastrophic breakdown of large scale econometric models during the inflation of the 1970s was almost solely due to the fact that they contained equations implying the existence of a long-run inflation unemployment trade-off. That the failure of one equation (or block of equations), only recently developed, should lead, as Lucas and Sargent (1978) were later to 
claim, to the demise of Keynesian economics is surprising. To begin with, there was more to Keynesian economics than large forecasting models. Moreover, the failure of one equation did not logically require the radical transformation of the structure of macroeconomic analysis which the proponents of New-classical economics set in motion. Indeed, the monetary model of the cycle which they proposed as the alternative to the Keynesian analysis embodied in the large econometric models of the 1970s was from the outset empirically suspect in its own way: that model has output fluctuations occurring as a response to misperceived price levels, and hence cannot cope with the fact that output fluctuations lead those in the inflation rate at cyclical turning points. The New-classical revolution was, however, brought about more by the attractive elegance of its theoretical models, not to mention its proponents' persuasive use of language as by the empirical content of their case.

Lucas (1977) argued that the Phelps-Friedman critique of the Phillips curve had amounted to much more than a suggestion that an extra variable, carrying a particular coefficient, should be added to the equation. Rather, he pointed out, that critique had been based on the contention that the equation should be constrained to reflect equilibrium behaviour. In this Lucas was quite correct, and as things subsequently transpired, the collapse of the Phillips trade-off involved a victory for those who had insisted on the validity of equilibrium theory over those who had relied on empirical evidence to discipline their work. ${ }^{15}$ Hence the episode seemed to vindicate one methodological criterion and weaken the status of another. In this context, the word equilibrium can only be construed to refer to the behaviour of maximising agents whose plans concern real (not nominal) magnitudes, and are executed. Since, it is hard to see how economics could have any predictive content if the plans of individuals were not executed and therefore did not produce observable consequences, it is difficult to regret that vindication. 
It is, however, a non-sequitur to go on to argue that, because macroeconomics is concemed with the economy as a whole, the same methodological criterion requires that it should concem itself only with situations of general equilibrium in which the plans of all agents are rendered compatible with one another by the operation of flexible prices. Nevertheless, that is how New-classical economists did, and continue to, argue; and the history of macroeconomics over the past fifteen years bears eloquent witness to the persuasiveness of their non-sequitur, and to the attractive tractability of the theoretical models which adherence to it enabled them to build. ${ }^{16}$ I have written elsewhere (e.g. Laidler 1990a, Ch. 4) about this more recent history, and at this conference it is dealt with by Olivier Blanchard and Robert King. For purposes of this paper it is sufficient to point out: that the practice of treating the expectations augmented Phillips curve as an aggregate supply relationship, forced upon New-classical economics by its adoption of Walrasian foundations, led it to develop, not a more refined version of an already existing monetary impulse theory of the cycle, but a radically different theory; and that it is this radically different theory which has been found empirically wanting in the last decade, rather than the general hypothesis that monetary impulses are important.

It was, and is, possible to construct a model that captures the essential insights of a late 1960 s monetarist view of macroeconomic processes, including those concerning the absence of any long-run inflation unemployment trade-off, but which is also compatible with the basic stylised facts of the cycle as summarised by, say, Kydland and Prescott (1990). This author constructed and estimated the prototype of just such a model in (1973). It consisted of three equations: an income velocity formulation of the quantity theory, an expectations augmented Phillips curve linking price inflation to real output's deviation from trend, and - dare one still mention it - a first order error-leaming characterisation of the formation of inflation expectations. It yielded three key predictions: that the critical exogenous monetary variable on the right hand side of the reduced form equation for output's deviation from trend was indeed, as Friedman had suggested, the rate of growth of the nominal money supply; that it 
was inflation's rate of change which varied with the deviation, and rate of change of that deviation, of output from trend; and that there would be a damped cyclical response to a monetary shock, with the rate of inflation lagging a bit less than one quarter cycle behind output, so that the price level was an inherently counter-cyclical variable.

Now the model to which I am here referring was in no sense an outlier in the literature of its time. It was, in fact, a "bare bones" version of a framework that could easily be extended so as to: incorporate the kind of financial stock-flow interaction discussed by Friedman and Schwartz (1963b) or Karl Brunner (1961), and endogenous fluctuations in nominal interest rates too; test for, and confirm, the presence of other than monetary shocks as a source of real

fluctuations; and cope with balance of payments phenomena in an open economy setting. ${ }^{17}$ In short, a small Monetarist model of early 1970s vintage turned out to be a limiting case of a more eclectic Keynesian model. With rather minor extension, moreover, it was capable of tracking some data as well as, and other data better than, say Barro's (1978) New-classical system. From the point of view of the model's mechanics, there is no mystery about why this proved to be so. First, and crucially different from any monetary New-classical model, it incorporated the idea that in response to a monetary shock, output changes preceded those in the inflation rate, and second, the inclusion of a geometrically declining weighted average of past values of the inflation rate on the right hand side of the Phillips curve guaranteed considerable inertia to the predicted behaviour of inflation. Since these are properties of the data, the model could not help but fit them. ${ }^{18}$

THE LESSONS OF THE DEBATES

Two points about the type of model just described are worth stressing. First, it can accommodate the idea that monetary changes are an important cyclical impulse, and 
simultaneously predict the key stylised facts about the business cycle which readers of Kydland and Prescott (1990) might think disqualify a monetary explanation from serious consideration; and second, its capacity to do so stems from its assuming price stickiness. It is this assumption which ensures that quantities begin to move before prices, and that the inflation rate displays inertia. But, of course, in the 1990s, price stickiness is the hallmark of so-called "New-Keynesian economics." Monetarism seemed, two decades ago, to provide a distinct approach to understanding the cycle. Nowadays it looks more like a particular version of the very orthodoxy to which it had at one time been diametrically opposed. This appearance is not just a matter of the vantage point from which we now view the macroeconomics of the 1960s and early 1970s. Friedman's debate with his critics, published in Gordon (1974) showed that most of their differences, though deep and important, were nevertheless were more quantitative than qualitative, and further movement towards a synthesis of monetarist and Keynesian views was in fact implicit in the debates which I have described earlier in this paper.

Those debates seemed to establish that monetary impulses had been far more important in generating economic instability than the Keynesian economics of the 1950 s would have had it. They also seemed to establish that a long run inflation-unemployment trade-off, which could be treated as defining a policy menu, did not exist. Keynesian economics had to absorb these lessons if it was to continue as an empirically viable and policy relevant body of doctrine; and it did so. But the story is not of the universal triumph of monetarist ideas. To establish monetary instability as an important source of cyclical impulse and propagation mechanisms does not also establish its general dominance in either role. To begin with any cycle theory has to address the fact of the relatively large amplitude of variations in investment, and a purely monetary approach seems to have little to say about the matter. Moreover the debates which I have described stopped far short of establishing the unimportance of non-monetary cyclical impulses. Anyone who was still in doubt about the lessons of the historical evidence 
on this matter in the early 1970s, was soon confronted with the effects of OPEC's activities on the economy's behaviour. Monetarists had to absorb that lesson, as they did the evidence which the 1970s produced about the sensitivity of the demand for money function to institutional change, and its implications for the effectiveness of a legislated money growth rule as a built in stabiliser. ${ }^{19}$

This is not to say that there would have been nothing to argue about by the mid-1970s had New-classical economics not come upon the scene, but it is to say that the differences between that body of theory and what had gone before it were far more profound than any that still needed settling between monetarists and Keynesians. The New-classical economists did not advance an alternative set of empirical hypotheses formulated within an already existing theoretical framework, whose validity could be judged by applying already accepted criteria. Rather they put forward an alternative theoretical framework whose superiority they defended with recourse to alternative methodological criteria. In their hands cycle theory became an application of general equilibrium analysis, and the approach was defended with reference, not so much to superior empirical content, as to its conformity with the theoretical principles of equilibrium modelling.

Even so, empirical evidence did play a role, if only a subsidiary one, in the literature of New-classical economics. Thus Lucas and Sargent (1978) made much of the breakdown of the permanent inflation-unemployment trade-off in their premature obituary of Keynesian economics, arguing, misleadingly, that only a model incorporating rational expectations could cope with the evidence of the 1970s. I have already commented on this, and on Kydland and Prescott's more recent efforts to use stylized facts as a way of distinguishing between various approaches to cycle theory. The acid test of New-classical economics' methodological priorities arises, however, with respect to its treatment of money wage and price stickiness. That many money wages and prices are subject to contractual arrangements which render them 
hand to change is beyond question, as it is that the incorporation of such a fact into any macroeconomic model gives it distinctly Keynesian characteristics. If we give priority to the facts in the selection of models, then we should let models which assume price stickiness stand or fall by their predictions. But because we do not by any means fully understand the nature of the underlying maximising behaviour that might lead to money wage and price stickiness New-classical economists refuse to take seriously the predictions of models that assume it. ${ }^{20}$ An important theme to emerge from the history recounted in this paper is, nevertheless, that it is dangerous to ignore micro-foundations. We have seen that models of consumption and investment behaviour based on maximising principles undermined multiplier accelerator analysis in the 1950s and 60s, and that the application of simple micro theory produced the expectations augmented Phillips curve, at a time when a simple permanent trade-off version of the relationship seemed confirmed by the facts. One can understand the attractiveness of equilibrium modelling in the light of this experience. But, to repeat a point made earlier, Walrasian general equilibrium modelling is a rather special case of that approach.

Only someone who believes that Walrasian general equilibrium theory embodies a set of first principles whose correct application will always guarantee the generation of scientific truth would refuse to entertain the possibility that the postulate of wage and price stickiness might not only generate better predictions, but might also, at some time in the future, be discovered to be quite compatible with maximising behaviour after all. To insist on explicit micro-foundations as a condition for taking an empirical hypothesis seriously is to indulge in what Karl Brunner, who discussed these matters extensively (for example in Brunner 1989), used to call the "Cartesian Fallacy" namely, the belief that there exist certain fundamental postulates from which scientific truth can be deduced, and, crucially, that we can know when such postulates have been discovered. Let us hope that this conference will help to reinstate empirical evidence as a factor more important than a priori principles reinforced by the deployment of persuasive language, in the ongoing debate about business cycles. 


\section{FOOTNOTES}

1. The quotation from Keynes comes from a New Statesman article of 1933. I have borrowed it from Elizabeth Johnson (1978) p. 20. The reader's attention is drawn to the fact that I do not here use the phrase "persuasive use of language" as synonymous with the word "rhetoric". As readers of McCloskey (1983) will understand, there is much more to the way in which economists converse with one another than their choice of words. This matter is, however, sometimes important - indeed to someone like myself who clings to the rather old-fashioned stance of attaching primary importance to the persuasive power of empirical evidence, it is occasionally too important!

2. Even "real-demand-side" models, of the multiplier-accelerator variety for example, require that the monetary system operate so as to prevent the rate of interest moving to equilibrate savings and investment at full employment if they are to generate cyclical fluctuations.

3. But, the data for the first half of this century do show prices to move procyclically. See Haberler (1956)p.133, Matthews (1959 p. 3), and indeed Lucas (1977) p.3. for assertions about this characteristic of the data. It is only in the post war period that this has ceased to be the case. The post-war reversal of the "loops" around the Phillips curve, discussed in $\mathrm{fn} .15$ reflect this change in the stylized facts.

4. Haberler (1937) still provides the best available survey of inter-war cycle theory. See Patinkin (1990) for a persuasive defence of IS-LM as a valid, though simplifying, account of the central theoretical content of the General Theory.

5. The American Economic Association produced two sets of readings in the area of business cycles - Haberler (ed.) (1944) and Klein and Gordon (eds.) (1965). A random inspection of old intermediate macroeconomics textbooks confirms that those of Day (1957), Dernberg and MacDougall (1960) Brooman (1962) all contained chapters on the cycle. Matthews (1959) was a widely used supplementary text of the same period. 
There is no reason to believe that this small sample of what students might have been asked to read three decades ago is unrepresentative, and in each case the cycle theory presented was of the multiplier-accelerator type.

6. Harrod (1936) and Samuelson (1939) should be credited with pioneering the analysis of multiplier-accelerator interaction as a key to cycle theory. Curious readers, whose training has been recent enough to leave them unfamiliar with the general nature of this class of models, are referred to Appendix A, where a simple generic example is briefly described.

7. The pioneering paper was surely that of Adelman and Adelman (1959).

8. The relevant papers of Friedman are reprinted as Chapters 9-12 in his (1969) collection The Optimum Quantity of Money. See also R. G. Gordon (ed.) (1974).

9. Though it is convenient to cite and quote Friedman and Schwartz's account of the transmission mechanism here, the reader should not be misled into believing that their account of it was in any way unique. Johnson (1962) noted that a variety of essentially similar accounts of the mechanism were at that time emerging in the literature, as much from Keynesians as from quantity theorists (as monetarists were then called). He quoted a lengthy section from Brunner (1961) to illustrate its properties.

10. In particular Friedman's downplaying of the importance of the interest sensitivity of velocity, most notable in (1959) but also apparent in Friedman and Schwartz (1963) attracted much comment before being finally laid to rest as an issue by Laidler (1966) and Friedman himself (1966). The question of interpreting the timing of data was most notably debated by Tobin and Friedman in their 1970 exchange in the Quarterly Journal of Economics.

11. Even so, this 1933-1937 episode still seems to me to be the most difficult one for a monetary explanation of the 1930 s to cope with. That surviving banks might want to build up free reserves in the wake of the bank failures of 1930-33 is not surprising, but 
that they should do so slowly over a four year period is much harder to understand. Morrison's (1966) explanation of the phenomenon is cast in terms of backward looking expectations, and would be well worth some new analysis. The reader's attention is drawn to the fact that the emphasis of monetarist analysis of the 1930s is on the behavior of the money supply. Other commentators, eg. Bernanke 1983 while focussing on events in the banking system, stress the destruction of the information processing and decision co-ordinating capacity of the financial sector as an important element in the propagation of the great depression, rather than the mere contraction of the money supply.

12. And, as Johnson (1962) noted at the time, a Keynesian could take considerable comfort from the fact that a theory designed to explain fluctuations in income during periods of chronic unemployment seemed capable of doing just that.

13. This is the view of Brunner and Meltzer (1987).

14. Two points are worth making about Phillips' contribution. First, the major finding of his research on stabilisation policy, which utilised his engineer's knowledge of control mechanisms, was that feed back rules had to be extremely carefully designed and implemented if they were not to be actively destabilising, so that Phillips himself was very nearly as skeptical as Friedman about the feasibility of "fine tuning". Second, according to Conrad Blyth (1987), the Phillips curve itself began life as an attempt to meet Sir Dennis Robertson's criticism that Phillips' earliest work concentrated too exclusively on real variables. That the analytical centrepiece of the Keynesian econometric models which were later to be so confidently used to design stabilisation policies should have such a pedigree is ironic, to say the least.

15. But is should be noted that Phillips' original empirical results still need to be explained. They show pro-cyclical behaviour of the inflation rate, rather than the price level, but the presence of counter-clockwise loops around the relationship in earlier years (they are clockwise in post-war data) tends to make inflation lead the cycle, and hence to 
make the price level itself pro-cyclical, thus reflecting the stylised facts referred to in footnote 3 above. Presumably the relatively constant inflation expectations existing in Britain under the Gold Standard, and under the Bretton Woods System go a long way towards explaining the appearance of a stable inflation-unemployment trade-off before 1914, and during the 1950s. The inter-war years never did generate so well defined a relationship. During the 1960s, and with considerable perceptiveness, G.C.Archibald used to refer in conversations to this phenomenon as "the econometric consequences of Mr. Churchill". And, of course, the disappearance of the Phillips curve in the 1970s came immediately after the breakdown of the Bretton Woods system.

16. This is not the place to rehearse well known arguments about the appropriateness or not of assuming price-stickiness in the absence of a widely accepted micro-economic explanation of the phenomenon. The argument that the behaviour of prices ought to be explained as the outcome of maximising behaviour is unexceptionable, but does not suffice to defend New-classical analysis, since, in a competitive model, it is well known that all endogenous agents are price takers, and that such a model cannot explain how prices are set. Since I know of no well articulated microeconomic explanation of money price flexibility, and since stickiness of many money prices does seem to be a well documented fact, I agree wholeheartedly with Brunner (1989) on the appropriateness of making the assumption in question.

17. The reader who is interested in the formal properties of this type of model is referred to Appendix B, where these are briefly described. The most complete extension of this line of research into a macroeconometric model is surely to be found in the publications of Peter Jonson and his associates at the Reserve Bank of Australia. See Jonson, Moses and Wymer (1976) and Jonson and Trevor (1979). These models were differentiated from contemporary Keynesian models by their relatively small size $(<30$ behaviour equations), their emphasis on the importance of monetary impulses, and their lack of a long-run inflation-unemployment trade off. With hindsight, their similarities 
to Keynesian models, which stem from the assumption that wages and prices adjust slowly to market disequilibrium over real time, are more striking than the differences. It is worth noting that these models are not simply systems of independently estimated equations, but incorporate the cross-equation restrictions implied by the theoretical analysis of stock-flow interaction that lies at the heart of the monetarist analysis of the transmission mechanism. It is also worth noting that they represent a product of the research agenda begun by Phillips in (1954) and continued by Rex Bergstrom and Clifford Wymer (1974). Finally, it should be pointed out that small empirical models were not a complete monetarist monopoly. Benjamin Fredman (1977), for example presents a five equation model of a very Keynesian type.

18. For a small model of the U.S. economy with these characteristics, whose results are directly comparable (and are compared) to those obtained by Barro (1978), see Laidler and Bentley (1983).

19. The relevant literature as far as the United States is concerned was ably surveyed by Judd and Scadding (1982). My own views on the significance of the evidence on the instability of the demand for money function that emerged in the 1970s have most recently been set out in Laidler (1990b).

20. And given that, from the 1880 s onwards, money wage stickiness was the explanation of cyclical unemployment accepted by those whom we would nowadays classify as "classical" economists - eg. Alfred Marshall and A. C. Pigou among others - and that, in Chapter 19 of the General Theory Keynes made it quite clear that he did not believe that his own explanation of the phenomenon depended on such stickiness, the inappropriateness of the current usage of the adjectives "New-classical" and "New-Keynesian" could not be more total. It is, however, far too late to do anything about it. 


\section{Appendix A}

A Generic Model of Multiplier-Accelerator Interaction

Where $\mathbf{A}$ is real autonomous expenditure, $\mathrm{C}$ is real consumption, $\mathrm{I}$ is real investment, $\mathrm{Y}$ is real income, $s$ is the marginal propensity to save, and $v$ is the desired capital output ratio, we may write

(1) $\quad \mathrm{Y}=\mathrm{C}+\mathrm{I}=\mathrm{A}+(1-\mathrm{s}) \mathrm{Y}_{-1}+\mathrm{v}\left(\mathrm{Y}_{-1}-\mathrm{Y}_{-2}\right)$

so that

(2) $\quad \mathrm{Y}=\mathrm{A}+(1-\mathrm{s}+\mathrm{v}) \mathrm{Y}_{-1}-v \mathrm{Y}_{-2}$

Since steady state income, $\mathbf{Y}^{*}$ is given by $Y^{*}=A+X^{*}-s Y^{*}$

(3) $\mathrm{Y}^{*}=\frac{1}{1-\mathrm{s}^{\mathrm{A}}} \quad \mathrm{Y}^{*}=\frac{1}{\mathrm{~s}} \mathrm{~A}$ ?

The dynamics of income's deviation from this steady state $\hat{Y}$, are described by

(4) $\hat{\mathrm{Y}}=(1-s+v) \hat{\mathrm{Y}}_{-1}+v \hat{\mathrm{Y}}_{-2}$

In general, a difference equation of the form

$$
\begin{aligned}
& x-\alpha_{1} x_{-1}+\alpha_{2} x_{-2}=0 \text { is stable if and only if } \\
& \alpha_{1}-\alpha_{2}-1<0,-\alpha_{1}-\alpha_{2}-1<0 \text {, and } \alpha_{2}<1 .
\end{aligned}
$$

and will display cyclical characteristics if and only if

$$
\alpha_{1}^{2}-4 \alpha_{2}<0
$$

If $v>1$ and $s<1$, such a multiplier-accelerator system may or may not generate cycles, but will be explosive. This is the system that forms the starting point for Hicks (1951) cycle model. 


\section{Appendix B}

\section{A Generic Monetarist Model}

When $\mathrm{m}$ is the log of the nominal money supply, $\mathrm{y}$ the deviation of the log of real income from its steady state value $y^{*}, p$ the log of the price level, and $\Delta p^{e}$ the expected inflation rate, we may write the quantity theory equation as

(5) $\quad \Delta \mathrm{m}=b \Delta y+b \Delta y^{*}+\Delta p$

The expectations augmented Phillips curve as

$$
\Delta \mathrm{p}=\mathrm{gy}_{-1}+\Delta \mathrm{p}_{-1}^{\mathrm{e}}
$$

and the error learning hypothesis as

(7) $\Delta \mathrm{p}^{\mathrm{e}}=\mathrm{d} \Delta \mathrm{p}+(1-\mathrm{d}) \Delta \mathrm{p}_{-1}^{\mathrm{e}}$

This model yields, as a reduced form for $y$,

$$
y=\frac{1}{b}\left(\Delta^{2} m-\Delta^{2} y^{*}\right)+\frac{2 b-g}{b} y_{-1}-\frac{b-(1-d) g}{b} y_{-2}
$$

Application of the conditions for stability and cyclical behaviour set out in Appendix A will confirm that it is likely to be cycle prone, but that only if $\mathrm{g}$ is "large" relative to $\mathrm{b}$ will this model fail to converge on its steady state. The relationship between inflation and the cycle may be written as

(9) $\quad \Delta^{2} \mathrm{p}=\mathrm{g} \Delta \mathrm{y}_{-1}+\mathrm{dg} \Delta \mathrm{y}_{-2}$

With the rate of acceleration of prices thus a function of the rate of growth of income's deviation from trend and the lagged value of this variable, the price level clearly lags well behind income's deviation from trend, and hence the "cycle."

This model is described in detail, and estimated, in Laidler 1973. 


\section{REFERENCES}

Adelman I. and Adelman F. L. (1959) "The Dynamic Properties of the Klein-Goldberger Model" Econometrica reprinted in Gordon R. A. and Klein L. R. (1965)

Andersen L. C. and Jordan J. L. (1968) "Monetary and Fiscal Actions: a Test of Their Relative Importance in Economic Stabilisation" Federal Reserve Bank of St. Louis Monthly Review 50 (Nov).

Ando A. and Modigliani F. (1965) "The Relative Stability of Monetary Velocity and The Investment Multiplier" American Economic Review 55 (Sept.) 693-728

Bailey M. J. (1962) National Income and the Price Level New York, McGraw Hill

Barro R. J. (1978) "Unanticipated Money, Output, and The Price Level in The United States" Journal of Political Economy 86 (Aug.) 549-81

Bergstrom R. and Wymer C. R. (1974) "A Model of Disequilibrium Neo-classical Growth and its Application to The United Kingdom" LSE International Monetary Economics Research Programme (mimeo)

Bernanke B. (1983) "Non-Monetary Effects of the Financial Crisis in the Propagation of the Great Depression" American Economic Review 73 (June) 257-76

Blyth C. (1987) "A. W. Phillips" in Eatwell J., Millgate M. and Newman P. (eds) The New Palgrave London, Macmillan

Brooman F. (1962) Macroeconomics London, George Allen and Unwin

Brunner K. (1961) "The Report of the Commission on Money and Credit" Journal of Political Economy 69 (Dec.) 605-20 (1981) "Epilogue: Understanding the Great Depression" in Brunner K. (ed) The Great Depression Revisited The Hague, Martinus Nijhoff Publishing (1989) "The Disarray in Macroeconomics" in Capie F. and Wood G. E.

Monetary Economics in the 1990s London, Macmillan and Meltzer A. H. (1978) (eds.) The Problem of Inflation Carnegie Rochester

Conference Series vol. 8, Amsterdam, North Holland 
(1987) "Money and the Economy: Issues in Monetary Analysis"

The 1987 Raffaele Mattioli Lectures, Carnegie Mellon Univ. (mimeo)

Burns A. F. and Mitchell W. C. (1946) Measuring Business Cycles New York, NBER

Cagan P. (1965) Determinants and Effects of Changes in the Stock of Money 1870-1960

New York, Columbia Univ. Press for the NBER

Culbertson J. M. (1961) "Friedman on the Lag in Effect of Monetary Policy" Journal of

Political Economy 68 (Dec.) 617-21

Day A. C. L. (1957) Outline of Monetary Economics Oxford, The Clarendon Press

DePrano M. and Mayer T (1965) "Tests of the Relative Importance of Automonous

Expenditure and Money" American Economic Review 55 (Sept.) 729-52

Dernberg T. F. and McDougall D. M. (1960) Macroeconomics New York, McGraw Hill

Domar E. (1947) "Expansion and Employment" American Economic Review 37 (March)

Friedman B.M. (1977) "The Inefficiency of Short-run Monetary Targets for Monetary Policy"

Brookings Papers on Economic Activity 2. 293-346.

Friedman M. (1957) A Theory of the Consumption Function Princeton N. J., Princeton Univ.

Press for the NBER

(1958) "The Supply of Money and Changes in Prices and Output" JEC of 85th

Congress, Reprinted as Ch. 9 of Friedman (1969)

(1959) "The Demand for Money: Some Theoretical and Empirical Results"

Journal of Political Economy Reprinted as Ch. 6 of Friedman (1969) (1961) "The Lag in Effect of Monetary Policy" Journal of Political Economy

Reprinted as ch. 11 of Friedman (1969)

(1966) "Interest Rates and the Demand for Money" Journal of Law and

Economics Reprinted as ch. 7 of Friedman (1969)

(1968) "The Role of Monetary Policy" American Economic Review Reprinted

as ch. 5 of Friedman (1969)

(1969) The Optimum Quantity of Money and Other Essays London, Macmillan 
(1970) "Comment on Tobin" Quarterly Journal of Economics 84 (May) 318-27 and Meiselman D. (1963) "The Relative Stability of Monetary Velocity and the

Investment Multiplier in the United States 1898-1958" in Commission on Money and Credit Stabilization Policies Englewood Cliffs N. J., Prentice Hall and Schwartz A. J. (1963a) A Monetary History of the United States 1867-1960 Princeton N. J. Princeton Univ. Press for the NBER (1963b) "Money and Business Cycles" Review of Economics and Statistics Reprinted as ch. 10 of Friedman (1969)

Frisch R. (1933) "Propagation Problems and Impulse Problems in Dynamic Economics" in Economic Essays in Honour of Gustav Cassel Reprinted in Gordon R. A. and Klein L. R. (1965)

Gordon R. A. and Klein L. R. (eds) (1965) Readings in Business Cycles Homewood IIt. Richard Irwin, for the AEA

Gordon R. J. (ed) (1974) Milton Friedman's Monetary Framework Chicago Ill. Univ of Chicago Press

Haberler G (1937) Prosperity and Depression Revised edition reprinted (1964) Cambridge Mass. Harvard Univ. Press (ed) (1944) Readings in Business Cycle Theory Homewood Ill. Richard Irwin for the AEA (1956) "Monetary and Real Factors Affecting Economic Stability: a Critique of Certain Tendencies in Modern Economic Theory" Banca Nazionale del Lavoro Quarterly Review Reprinted in Gordon R. A. and Klein L. R. (1965) Harrod R. F. (1936) The Trade Cycle Reprinted 1965, New York, Augustus Kelley (1948) Towards a Dynamic Economics London, Macmillan Hicks J. R. (1949) "Mr. Harrod's Dynamic Theory" Economica Reprinted in Gordon R. A. and Klein L. R. (19650 
(1951) A Contribution to the Theory of the Trade Cycle London, Oxford

Univ. Press

Johnson E. S. (1978) "Keynes as a Literary Craftsman" in Johnson E. S. and Johnson H. G.

The Shadow of Keynes Chicago IIl. Univ. of Chicago Press

Johnson H. G. (1962) "Monetary Theory and Policy" American Economic Review 52 (June)

335-84

Jonson P. D. Moses E . R. and Wymer C. R. (1976) "A Minimal Model of the Australian Economy" Reserve Bank of Australia Discussion paper 7601, Sydney (mimeo) and Trevor R. G. (1980) "Monetary Rules: a Preliminary Analysis" Reserve Bank of Australia Discussion Paper 7903 (revised 1980) Sydnew (mimeo)

Jorgenson D. W. (1963) "Capital Theory and Investment Behaviour" American Economic

Review 53 (May) Papers and Proceedings 247-59

Judd J. and Scadding J (1982) "The Search for a Stable Money Demand Function: a Survey of the post-1973 Literature" Journal of Economic Literature 20 (Sept.) 993-1023

Knox A. D. (1952) "The Acceleration Principle and the Theory of Investment: a Survey" Economica NS. 19 (Aug.) 269-97

Koopmans T. C. (1947) "Measurement without Theory" *Review of Economics and Statistics* Reprinted in Gordon and Klein (1965)

Kydland F. and Prescott E. (1982) "Time to Build and Aggregate Fluctuations" Econometrica 50 (Sept.) 1345-70 (1990) "Business Cycles: Real Facts and a Monetary Myth"

Federal Reserve Bank of Minneapolis Quarterly Review (Spring) 3-18

Laidler D. (1966) "The Rate of Interest and the Demand for Money: Some Empirical Evidence" Journal of Political Economy 74 (Dec.) 545-55 (1973) "The Influence of Money on Real Income and Inflation: a Simple Model with Some Empirical Tests for the United States" 1953-72" Manchester School 41 (Dec.) 
(1990a) Taking Money Seriously Cambridge Mass. MIT Press

(1990b) "Understanding Velocity: New Approaches and Their Policy Relevance -

Introduction" Journal of Policy Modeling 12 (Summer) 141-64

and Bentley B. (1983) "A Small Macro-model of then Post-war United States"

Manchester School 51 (Dec.) 317-340

Lipsey R. G. (1961) "The Relationship between Unemployment and the Rate of Change of

Money Wage Rates in the United Kingdom 1862-1957" Economica NS. 27 (May)

115-38

Lucas R. E. jr (1977) "Understanding Business Cycles" in Brunner K. and Meltzer A. H.. (eds)

Stabilization of the Domestic and International Economy Camegie Rochester

Conference Series Vol. 5, Amsterdam, North Holland

and Sargent T. J. (1978) "After Keynesian Economics" in After the Phillips

Curve: Persistence of High Inflation and High Unemployment" Boston Mass., Federal

Reserve Bank of Boston

Matthews R. C. O (1959) The Business Cycle Chicago, Univ. of Chicago Press

Mayer T. (1978) "Consumption in the Great Depression" Journal of Political Economy 86

(Feb.) $139-46$

McCloskey D. (1983) "The Rhetoric of Economics" Journal of Economic Literature 21

(June) 481-517

Meade J. E. (1961) A Neoclassical Theory of Economic Growth London, Allen and Unwin

Modigliani F. and Brumberg R. (1954) "Utility Analysis and the Consumption Function: An

Interpretation of the Cross-Section Data" in Kurihara K (ed) Post Keynesian

Economics New Brunswick N. J., Rutgers Univ. Press

Morrison G. (1966) Liquidity Preferences of Commercial Banks Chicago, Univ. of Chicago

Press

Patinkin D. (1990) "In Defence of IS-LM" Banca Nazionale del Lavoro Quarterly Review

No. 172 (March) 119-34 
Phelps. E. S. (1967) "Phillips Curves, Expectations of Inflation, and Optimal Unemployment over Time" Economica NS 34 (Aug.) 254-81

Phillips A. W. (1954) "Stabilization in a Closed Economy" Economic Journal 64 (June) 290-323 (1968) "The Relation between Unemployment and the Rate of Change of Money Wages Rates in the United Kingdom" Economica NS 25 (Nov.) 283-99 Plosser C. (1990) "Money and Business Cycles: a Real Business Cycle Interpretation" in Belongia M. (ed) Monetary Policy on the 75th Anniversary of the Federal Reserve System St. Louis Mo., Federal Reserve Bank of St. Louis

Samuelson P. A. (1939) "Interactions between the Multiplier Analysis and the Principle of Acceleration" Review of Economics and Statistics 21 (May) 75-8

Solow R. M. (1956) "A Contribution to the Theory of Economic Growth" Quarterly Journal of Economics 70 (Feb.) (1968) "Recent Controversies in the Theory of Inflation: an Eclectic View" in Rousseas S. W. (ed) Proceedings of a Symposium on Inflation, its Causes, Consequences and Control Wilton Conn. Calvin K. Kazanjian Economics Foundation Swan T. W. (1956) "Economic Growth and Capital Accumulation" Economic Record 32 (Nov.)

Temin P. (1976) Did Monetary Forces Cause the Great Depression? New York, Norton Tobin. J. (1970) "Money and Income: Pot Hoc Ergo Propter Hoc?" Quarterly Journal of Economics 84 (May) 301-17; "Rejoinder" 328-29 (1972) "Inflation and Unemployment" American Economic Review 62 (March) $1-18$ 